\title{
TANGGUNGGUGAT KERUGIAN NASABAH ASURANSI TERHADAP KASUS GAGAL BAYAR PRODUK ASURANSI UNIT LINK
}

\author{
Lorina* \\ Program Studi Magister Kenotariatan, Fakultas Hukum, Universitas Surabaya
}

\begin{abstract}
Humans in any part of the world are approached at any time by disaster or risks that come and go, this needs to be addressed by the parties so that the funds that have been allocated for the needs that have been determined are not lost. With the growing needs of society and the efforts of insurance companies to increase revenue, the type of insurance has also increased. Unit link itself indeed combines insurance with investment. Many people are also interested in this insurance product. insurance companies, which sell very large unit-linked products, also have a large risk with many facts about the failure of insurance companies to pay to policyholders. Based on the explanation above, it attracts the attention of the author to examine how the liability of the customer's losses caused by the failure of insurance company payments on unitlinked products, because basically insurance is to protect the policyholder from possible risks but on the other hand with the investment value of the policy can it has been eroded because investment does not always bring benefits, especially in policies whose investments are invested in highly volatile stock mutual fund products. This research uses normative legal research methods, it is hoped that the public can be educated from this research to be more careful and separate insurance and investment. Obligations and rights of policyholders must be fulfilled first, and if the world economic conditions are not good, better investment in unit link products is withdrawn first considering the shaking of the world economy can reduce the benefits of policyholders.
\end{abstract}

Keyword: Insurance, Unit Link, Risk, Investment

\begin{abstract}
ABSTRAK
Manusia dibelahan dunia manapun setiap saat dihampiri oleh musibah maupun risiko yang datang silih berganti, hal ini perlu ditanggulangi oleh para pihak sehingga dana yang telah dialokasikan untuk kebutuhan yang sudah ditetapkan tidak hilang. Dengan berkembangnya kebutuhan masyarkat dan upaya perusahaan perasuransian untuk meningkatkan pendapatan maka jenis asuransi pun bertambah. Unit link sendiri memang menggabungkan antara asuransi dengan investasi. Masyarakat pun banyak yang tertarik dengan produk asuransi ini. perusahaan asuransi yang dalam penjualan produk unit link ini sangat besar, juga tersimpan risiko yang besar dengan banyaknya fakta kasus gagal bayar perusahaan asuransi kepada pemegang polis. Berdasarkan penjabaran diatas menarik perhatian penulis untuk meneliti bagaimanakah tanggunggugat kerugian nasabah yang diakibatkan oleh kegagalan pembayaran perusahaan asuransi pada produk Unit link, karena pada dasarnya asuransi adalah untuk melindungi pemilik polis dari risiko yang mungkin diterima tapi di lain sisi dengan adanya investasi nilai dari polis tersebut bisa saja tergerus karena investasi tidak selalu membawa keuntungan terutama pada polis yang investasinya ditanamkan di dalam produk reksadana saham yang sangat volatile. Penelitian ini ini menggunakan metode penelitian hukum normatif, diharapkan masyarakat pun bisa teredukasi dari penelitian ini untuk lebih berhati-hati dan memisahkan
\end{abstract}


antara asuransi dan investasi. Kewajiban dan hak dari pemilik polis harus dipenuhi terlebih dahulu, serta bila kondisi perekonomian dunia sedang kurang baik lebih baik investasi pada produk unit link ini ditarik terlebih dahulu mengingat goyanagan pada perekonomian dunia bisa mengurangi keuntungan pemilik polis.

Kata Kunci: Asuransi, Unit Link, Risiko, Investasi

\section{A. PENDAHULUAN}

\subsection{Latar Belakang}

Manusia dibelahan dunia manapun setiap saat dihampiri oleh musibah maupun risiko yang datang silih berganti, hal ini perlu ditanggulangi oleh para pihak sehingga dana yang telah dialokasikan untuk kebutuhan yang sudah ditetapkan tidak hilang. Misalnya pemilik usaha yang tokonya terbakar akan kesulitan untuk kembali berdagang karena barang modal yang ia jual sudah habis termakan api, maka dari itu perlu ditanggulangi dengan menggunakan asuransi sebagai proteksi diri dari kerugian yang tidak diinginkan. Asuransi berdasarkan pada Pasal 1 Angka 1 Undang-undang Nomor 40 Tahun 2014 tentang Perasuransian atau pertanggungan secara umum adalah perjanjian antara dua pihak yaitu perusahaan asuransi dan pemegang polis, yang menjadi dasar bagi pemerimaan premi oleh perusahaan asuransi.

Dengan berkembangnya kebutuhan masyarkat dan upaya perusahaan perasuransian untuk meningkatkan pendapatan maka jenis asuransi pun bertambah. Beberapa produk asuransi yang dikenal masyarakat adalah asuransi kesehatan, asuransi jiwa, asuransi pendidikan, asuransi kendaraan dan lainnya. kemudian pada Tahun 1998 poduk asuransi Unit Link dimunculkan. Unit link sendiri memang menggabungkan antara asuransi dengan investasi. Masyarakat pun banyak yang tertarik dengan produk asuransi ini.

Diluar uephoria masyarkat dan perusahaan asuransi yang dalam penjualan produk unit link ini sangat besar, juga tersimpan risiko yang besar dengan banyaknya fakta kasus gagal bayar perusahaan asuransi kepada pemegang polis. Pada tahun 2008 perusahaan asuransi Bakrie Life gagal bayar untuk produk asuransi jiwa berbasis investasi dengan produk "Diamond Investa", kegagalan bayar ini menurut pihak Bakrie Life diakibatkan oleh krisis keuangan yang membuat investasi rontok dan mengakibatkan dana nasabah sebanyak Rp. 360 Milyar hilang tidak kembali. Permasalahan ini pun berlanjut pada perusahaan AJB Bumiputera dan Asuransi Jiwasraya menjadi perusahaan yang mengalami kegagalan membayar kewajiban kepada 
para pemegang polis. ${ }^{1}$ Pada asuransi Jiwasraya ${ }^{2}$ gagal bayar ini melibatkan 711 polis senilai Rp802 miliar.

Otoritas Jasa Keuangan (OJK) selaku regulator dan pengawas di sektor asuransi sendiri dinilai kurang tegas dalam menyelesaikan permasalah ini, hal ini terbukti ketika pada penyelesaian permasalahan AJB Bumiputera, dimana OJK sempat menetapkan Pengelola Statuter yang melaksanakan kewenangan OJK tetapi jalan keluar yang diberikan oleh Pengelola Statuter gagal di tengah jalan, sehingga OJK pun mengembalikan pengelolaan AJB Bumiputera kepada pemegang polis yang hingga masih mengalami jalan buntu.

Berdasarkan penjabaran diatas menarik perhatian penulis untuk meneliti bagaimanakah tanggunggugat kerugian nasabah yang diakibatkan oleh kegagalan pembayaran perusahaan asuransi pada produk Unit link, karena pada dasarnya asuransi adalah untuk melindungi pemilik polis dari risiko yang mungkin diterima tapi di lain sisi dengan adanya investasi nilai dari polis tersebut bisa saja tergerus karena investasi tidak selalu membawa keuntungan terutama pada polis yang investasinya ditanamkan di dalam produk reksadana saham yang sangat volatile. keberadaan asuransi yang disertai dengan investasi sifatnya sangat berbeda, satu melindungi nilai dan satunya bisa mengurangi nilai. Dari penelitian ini diharapkan bisa memberikan pandangan kepada masyarakat terkait asuransi unit link dengan kelebihan dan kekurangannya sehingga bila dikemudian ada permasalahan masyarakat bisa memahami upaya penyelesaiannya.

\subsection{Rumusan Masalah}

1. Apa saja jenis Produk asuransi beserta kelebihan dan kekurangannya berdasarkan Undangundang Nomor 40 Tahun 2014 tentang Perasuransian?

2. Bagaimanakah upaya penyelesaian permasalahan gagal bayar pada produk asuransi Unit Link?

\subsection{Tujuan}

1. Memahami kelebihan dan kekurangan produk asuransi yang bisa dipergunakan oleh masyarkat terutama produk asuransi Unit Link

2. Mengetahui Penyelesaian permasalahan gagal bayar pada produk asuransi unit link

\section{B. METODE PENELITIAN}

Penelitian ini ini menggunakan metode penelitian hukum normatif, yaitu penelitian hukum yang mengkaji hukum tertulis dari berbagai aspek, yaitu aspek teori, sejarah, filosofi, perbandingan,
1 Christine Nababan (2019). INFOGRAFIS: Deretan Kasus Gagal Bayar Asuransi Raksasa. https://www.cnnindonesia.com/ekonomi/201904050 65809-81-383575/infografis-deretan-kasus-gagalbayar-asuransi-raksasa. diakses pada 5 Desember 2019 jam 09.37 WIB.
${ }^{2}$ Risca Vilana (2019). Pamor Unit dan Link Saving Plan Setelah Kasus Jiwasraya. http://infobanknews.com/pamor-unit-link-dansaving-plan-setelah-kasus-jiwasrayal. diakses pada 3 Desember 2019 jam 11.45 WIB. 
struktur dan komposisi, lingkup dan materi, konsistensi, penjelasan umum pasal demi pasal, formalitas dan kekuatan mengikat suatu undang-undang, serta bahasa hukum yang digunakan, tetapi tidak mengkaji aspek terapan atau implementasinya ${ }^{3}$ dan Penelitian ini menggunakan pendekatan yaitu pendekatan perundang-undangan (statute approach) dan pendekatan kasus (case approach) ${ }^{4}$

C. PEMBAHASAN

\section{Jenis Produk Asuransi}

Dasar Hukum Perasuransian awalnya diatur di dalam Undang-undang Nomor 12 Tahun 1992, yang kemudian diperbarui dengan Undangundang Nomor 40 Tahun 2014 (UU Perasuransian). Pembaruan ini dinilai diperlukan karena undang-undang yang lama sudah tidak sesuai dengan perkembangan dan kebutuhan masyarakat. Asuransi menurut UU Pasal 1 Angka 1 Asuransi adalah perjanjian antara dua pihak, yaitu perusahaan asuransi dan pemegang polis, yang mennjadi dasar bagi penerimaan premi oleh perusahaan asuransi sebagai imbalan untuk:

a. memberikan penggantian kepada tertanggung atau pemegang polis karena kerugian, kerusakan, biaya yang timbul, kehilangan keuntungan, atau tanggung jawab hukum kepada pihak ketiga yang mungkin diderita tertanggung atau pemegang polis karena terjadinya suatu peristiwa yang tidak pasti;atau

b. memberikan pembayaran yang didasarkan pada meninggalnya tertanggung atau pembayaran yang didasarkan pada hidupnya tertanggung dengan manfaat yang besarnya telah ditetapkan dan/atau didasarkan pada hasil pengelolaan dana.

Ruang lingkup usaha perasuransian diatur pada Pasal 2 dan Pasal 3 Undang-undang Nomor 40 Tahun 2014 yang mengatur asuransi umum konvensional dan asuransi umum syariah.

Pada pasal 2 ayat $1 \mathrm{UU}$ Perasuransian, asuransi umum hanya dapat menyelenggarakan:

a. Usaha asuransi umum, termasuk lini usaha asuransi kesehatan dan lini asurans kecelakaan diri; dan

b. Usaha Reasuransi untuk risiko Perusahaan Asuransi Umum lain

Sedangkan pada Pasal 2 ayat 2 UU Perasuransian, Perusahaan asuransi jiwa hanya dapat menyelenggarakan Usaha Asuransi Jiwa termasuk lini usaha anuitas, lini usaha asuransi kesehatan, dan lini usaha asuransi kecelakaan diri. sehingga pada umumnya hanya ada 2 (dua) jenis asuransi yang paling penting yaitu Asuransi Kesehatan dan Asuransi Jiwa meskipun kemudian produk
3 Zainudin Ali. (2011). Metode Penelitian Hukum. Jakarta: Sinar Grafika, 2011, hal: 18.
4 Peter Mahmud Marzuki. (2013). Penelitian Hukum, Edisi Revisi, Cet.8, Jakarta: Kencana Prenada Group, hal: 47, 133. 
asuransi ini berkembang sesuai dengan kebutuhan masyarakat seperti asuransi pendidikan, asuransi kendaraan, asuransi properti, asuransi Unit Link dan asuransi lainnya. perusahaan asuransi jiwa pun terus mengembangkan produknya agar menjadi produk asuransi yang makin menarik bagi masyarakat dengan tujuan untuk meningkatkan utilitas masyarakat terhadap produk asuransi. Salah satu produk asuransi jiwa yang saat ini paling banyak ditawarkan oleh perusahaan asuransi adalah produk asuransi unit link.

menurut Kitab Undangundang Hukum Dagang Indonesia, perjanjian asuransi memiliki beberapa prinsip yakni:
a. Prinsip Kepentingan yang dapat diasuransi (Insurable Interest)
b. Prinsip Keterbukaaan (Utmost Good Faith)
c. Prinsip Indemnitas (Indemnity)
d. Prinsip Subrogasi
e. Prinsip Sebab Akibat (Proximate Cause)
f. Prinsip Gotong Royong

\section{Permasalahan dalam Asuransi Unit Link}

Unit link adalah jenis asuransi yang mengombinasikan dua produk keuangan, yakni asuransi dan produk investasi. Asuransi ini mengkombinasikan dua produk keuangan yaitu asuransi dan produk investasi. Pada keranjanjang produk investasi biasanya dikelolah oleh Manajer Investasi berupa produk Reksadana. Sebagian besar premi yang dihasilkan pada industri asuransi berasal dari jenis usaha asuransi jiwa, dimana jenis produk dengan pendapatan premi tertinggi adalah produk asuransi unit link. Produk asuransi ini mampu menumbuhkan kesadaran masyarakat dalam berasuransi sekaligus berinvestasi ${ }^{5}$

Sebelum membeli produk ini pasatikan pemahaman terkait dengan kelebihan dan kekurangannya. Pada beberapa negara sering terjadi mis-selling atau kesalahan dalam penjualan unit link, yaitu menjual produk link yang tidak sesuai dengan perencanaan keuangan nasabah dengan mnggunakan asumsi yang kurang realistis dalam memberikan ilustrasi pemanfaatan produk Unit Link. Pemilik polis harus memahami polis yang ditandatangani. Polis adalah kontrak dan perjanjian asuransi, serta merupakan dasar penggantian dan atau pembayaran klaim di masa datang. ${ }^{6}$

Berdasarkan penempatan dana investasinya, asuransi unit link dibagi menjadi Asuransi Unit Link Pasar Uang, Asuransi Unit Link Pendapatan Tetap,

\footnotetext{
${ }^{5}$ Kajian Perlindungan Konsumen sektor jasa keuangan Asuransi Unit LInk https://konsumen.ojk.go.id/MinisiteDPLK/images/u pload/201807131517583.\%20Unitlink.pdf.
}

\footnotetext{
${ }^{6}$ Freddy Pieloor. (2009). Jangan Beli Unit Link, Bila anda tidak paham benar!. Jakarta: Elex Media Komputindo, Cet. I, hal: 25
} 
Asuransi Unit Link Pendapatan

Campuran, dan Asuransi Unit

Link Dana Saham. berdasarkan pembayaran premi, asuransi unit link dikelompokkan menjadi premi tunggal dan premi berkala. Dasar hukum keberadaan Unit Link sendiri telah diatur oleh OJK dengan mengeluarkan Peraturan OJK Nomor 23/POJK.05/2015 tentang Produk Asuransi dan Pemasaran Produk dan Keputusan Ketua Badan Pengawas Pasar Modal dan Lembaga Keuangan Nomor KEP-104/BL/2006 tentang Produk Unit link.

Pembayaran iuran premi pada asuransi unit link ini tidak bisa ditarik dan bila ditarik sebelum habis jangka waktunya akan memunculkan sanksi berupa potongan jumlah dana yang akan diterima. Ada tiga penyebab utama tergerusnya iuran premi yaitu: ${ }^{7}$

a. Potongan Komisi yang besar

besarnya potongan terhadap premi untuk membayar komisi kepada agent dan perusahaan asuransi, Jumlah potongan cukup besar. Mulai dari 100\%, lalu 55\% sampai $10 \%$ di akhir tahun ke 5. Baru setelah tahun ke 6, pemegang polis tidak kena potongan. Komisi ini semuanya dipotong didepan. Mau hasil investasi bagus atau jelek, komisi tetap dipotong up-front. Dengan potongan komisi sebegitu besar, tidak heran sisa premi yang bisa diambil oleh nasabah menjadi sangat minimal.

premi yang dibayarkan nasabah unit link terbagi dalam dua bagian:

(a) premi untuk asuransi dan (b) premi untuk investasi.

b. Kinerja Investasi buruk maka prediksi dalam proposal tidak akan terjadi

pembayaran premi tersebut diinvestasikan oleh perusahaan asuransi ke instrumen keuangan. premi yang bisa diambil adalah hasil dari perputaran di instrumen investasi, anjloknya kinerja investasi akan menggerus nilai premi yang sudah dibayar peserta. Kalau sudah tergerus, pemegang polis tidak bisa mengambil premi. Terutama pada produk yang diinvestasikan pada reksadana saham, dalam saham berlaku hukum High Risk, High Return, meski begitu tidak ada satupun aturan hukum yang melarang pilihan saham-saham berisiko yang dipilih
7 Rio. (2017). Kenapa Premi Asuransi Jiwa Unit Link Anda, Tidak Kembali Semua? https://duwitmu.com/asuransi/kenapa-premi- asuransi-jiwa-unit-link-tidak-kembali/. Diakses tanggal 3 Desember 2019 jam 15.00 WIB. 
oleh Manajer Investasi

(MI) sehingga segala

risiko tetap ditanggung

oleh pemilik polis,

ketika rugi MI tetap

untung, ketika investasi

tersebut untung MI lebih

untung lagi berdasarkan

fee yang rutin dibayar

pemegang polis.

c. Potongan biaya admin

biaya admin atas penambahan investasi,

Setiap kali pemegang polis menambah

investasi, maka asuransi akan memotong biaya admin, sebesar 5\% dari nilai top up.

Berdasarkan data

pada Layanan Konsumen

OJK dan laporan penanganan pengaduan yang disampaikan oleh perusahaan asuransi kepada OJK melalui Sistem Pelaporan Edukasi dan Perlindungan Konsumen (SIPEDULI). Pokok permasalahan pengaduan yang sering disampaikan oleh konsumen adalah terkait keberatan atas hasil investasi dan perilaku agen asuransi. Terkait hasil investasi, konsumen merasa dirugikan karena hasilnya yang tidak sesuai dengan persentase yang diperjanjikan atau disebutkan pada polis. Permasalahan yang dialami

$$
\begin{array}{lr}
\begin{array}{lr}
\text { konsumen } \\
\text { disebabkan }
\end{array} & \begin{array}{r}
\text { seringkali } \\
\text { karena }
\end{array} \\
\text { rendahnya } & \text { tingkat } \\
\text { pemahaman } & \text { masyarakat } \\
\text { terhadap produk } & \text { keuangan } \\
\text { yang } & \text { digunakannya. } \\
\text { Konsumen } & \text { membeli dan } \\
\text { menggunakan } & \text { produk } \\
\text { keuangan tanpa memahami } \\
\text { dengan } & \text { sepenuhnya } \\
\text { karakteristik } & \text { produk, } \\
\text { kesesuaian } & \text { dengan } \\
\text { kebutuhannya, } & \text { manfaat, } \\
\text { biaya dan risikonya }
\end{array}
$$

\section{Upaya Penyelesaian perkara gagal bayar pada Produk Asuransi Unit Link}

Dalam penyelesaian
permasalahan gagal bayar
Produk Asuransi Unit Link
perlu dipahami hak dan
kewajiban yang harus diterima
dan dilakukan oleh nasabah
asuransi yang meliputi:
1. Hak untuk mendapatkan
keterangan atau transparansi
tentang segala hal yang
berkaitan dengan manfaat dan
jaminan produk asuransi.

2. Hak untuk didengar pendapat dan keluhan tentang pelayanan yang diberikan oleh perusahaan asuransi.

3. Hak untuk mendapatkan ganti kerugian atas suatu peristiwa yang terjadi terhadap diri nasabah.

4. Kewajiban nasabah dalam membayar premi asuransi sesuai dengan lamanya masa asuransi yang disepakati.
8 Achmad Azhari Azis. (2019). Perlindungan Hukum Terhadap Nasabah Asuransi Produk Prestigio Ditinjau Dari Undang-Undang Nomor 40 Tahun 2014 Tentang Perasuransian (Studi Kasus Pada
Asuransi Zurich Topas Life Agency Palu). Jurnal Ilmu Hukum. Vol. 7 Edisi 4, hal: 1015. 
5. Kewajiban nasabah untuk patuh dan mengikuti segala hal yang sudah ditetapkan dalam polis asuransi.

OJK sebagai lembaga independen yang salah satu tujuanya adalah untuk melindungi kepentingan konsumen dan masyarkat di sektor jasa keuangan telah menerbitkan Peraturan Otoritas Jasa Keuangan (POJK) Nomor 1/POJK.07/2013 tentang Perlindungan Konsumen Sektor Jasa Keuangan. Berdasarkan ketentuan-ketentuan dimaksud, OJK telah menyediakan sarana dan mekanisme pelayanan pengaduan konsumen di sektor jasa keuangan. perusahaan asuransi, perlu menyusun kertas kerja dalam menawarkan asuransi unit link, melaksanakan welcome call dengan metode open question, memastikan mencantumkan seluruh biaya pada laporan perkembangan dana, memberikan rincian perhitungan pengembalian premi, dan mencantumkan data historis kinerja investasi pada ilustrasi.

Konsumen dan masyarakat, wajiib memahami produk unit link yang akan digunakannya dengan meminta penjelasan secara rinci kepada agen terkait manfaat, biaya, dan risiko pada produk asuransi unit link dan memahami seluruh ketentuan polis. Secara ringkas menurut peneliti asuransi hanya dipergunakan untuk melindungi pemilik polis dari risiko, sehingga bila digabungka dengan investasi bisa menjadi bomerang dan imbal hasil tidak akan maksimal.

\section{KESIMPULAN}

Dari penelitian diatas dapat disimpulkan bahwa asuransi unit link ini merupakan asuransi gabungan antara proteksi dan investasi, sehingga memiliki risiko yang cukup tinggi. Banyaknya kasus gagal bayar menjadi contoh betapa volatile nya produk ini, sehingga diharapkan masyarakat pun bisa teredukasi dari penelitian ini untuk lebih berhati-hati dan memisahkan antara asuransi dan investasi. Kewajiban dan hak dari pemilik polis harus dipenuhi terlebih dahulu, serta bila kondisi perekonomian dunia sedang kurang baik lebih baik investasi pada produk unit link ini ditarik terlebih dahulu mengingat goyanagan pada perekonomian dunia bisa mengurangi keuntungan pemilik polis.

\section{DAFTAR PUSTAKA}

\section{Daftar Buku}

Zainudin Ali. (2011). Metode Penelitian Hukum. Jakarta: Sinar Grafika, 2011, hal: 18.

Peter Mahmud Marzuki. (2013). Penelitian Hukum, Edisi Revisi, Cet.8, Jakarta: Kencana Prenada Group, hal: 47, 133.

Freddy Pieloor. (2009). Jangan Beli Unit Link, Bila anda tidak paham benar!. Jakarta: Elex Media Komputindo, Cet. I, hal: 25

\section{Perundang-undangan}

Undang-undang Nomor 40 Tahun 2014 tentang Perasuransian 
Peraturan OJK Nomor 23/POJK.05/2015 tentang Produk Asuransi dan Pemasaran Produk

Keputusan Ketua Badan Pengawas Pasar Modal dan Lembaga Keuangan Nomor KEP-104/BL/2006 tentang Produk Unit link.

\section{Karya Ilmiah (skripsi)}

Achmad Azhari Azis. (2019). Perlindungan Hukum Terhadap Nasabah Asuransi Produk Prestigio Ditinjau Dari Undang-Undang Nomor 40 Tahun 2014 Tentang Perasuransian (Studi Kasus Pada Asuransi Zurich Topas Life Agency Palu). Jurnal Ilmu Hukum. Vol. 7 Edisi 4, hal: 1015.

\section{Jurnal}

Christine Nababan (2019). INFOGRAFIS: Deretan Kasus Gagal Bayar Asuransi Raksasa.

https://www.cnnindonesia.com/ekonomi/20 190405065809-81-383575/infografisderetan-kasus-gagal-bayar-asuransiraksasa. diakses pada 5 Desember 2019 jam 09.37 WIB.

Risca Vilana (2019). Pamor Unit dan Link Saving Plan Setelah Kasus Jiwasraya. http://infobanknews.com/pamor-unit-linkdan-saving-plan-setelah-kasus-jiwasrayal. diakses pada 3 Desember 2019 jam 11.45 WIB.

${ }^{1}$ Kajian Perlindungan Konsumen sektor jasa keuangan Asuransi Unit LInk https://konsumen.ojk.go.id/MinisiteDPLK/i mages/upload/201807131517583.\%20Unit link.pdf.

Rio. (2017). Kenapa Premi Asuransi Jiwa Unit Link Anda, Tidak Kembali Semua? https://duwitmu.com/asuransi/kenapapremi-asuransi-jiwa-unit-link-tidak- kembali/. Diakses tanggal 3 Desember 2019 jam 15.00 WIB. 